UDC 621.313.13

SCOPUS CODE 2102

https://doi.org/10.36073/1512-0996-2021-3-69-75

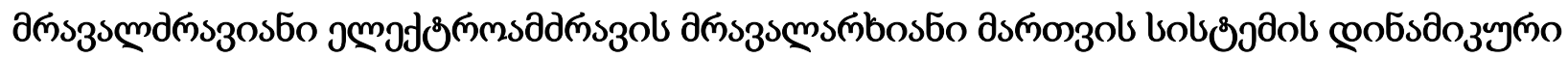

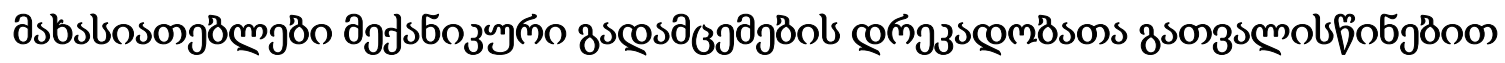

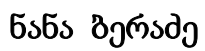

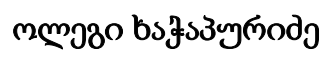

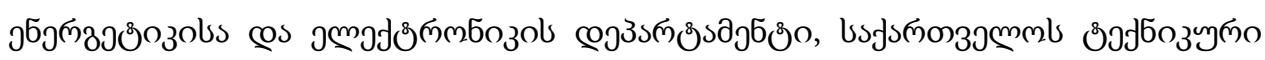

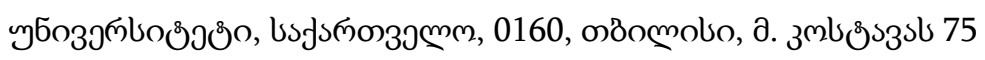

E-mail: beradzenana@gmail.com

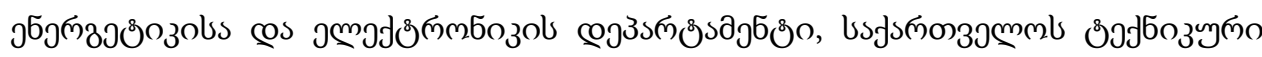

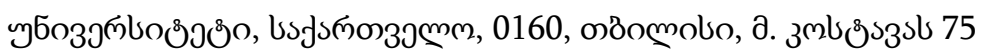

E-mail: o.khachapuridze@gtu.ge

\section{๓ว}

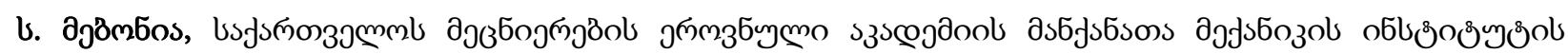

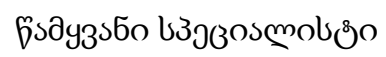

E-mail: meboniaslava@mail.ru

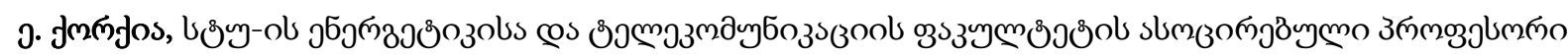

E-mail: e.korkia@gtu.ge

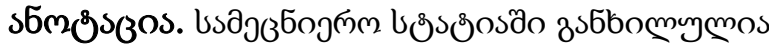

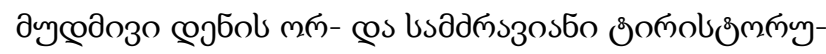

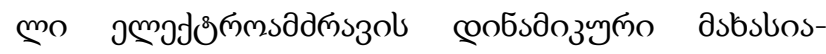

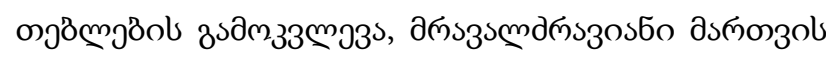

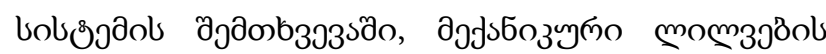

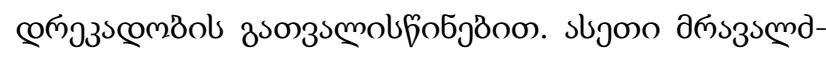

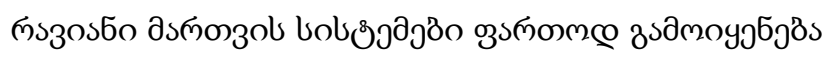

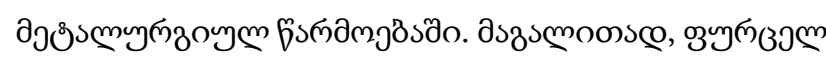

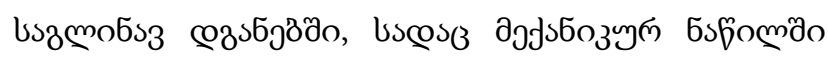

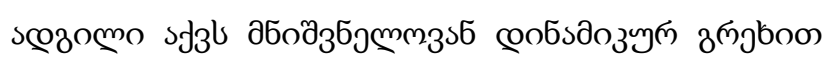

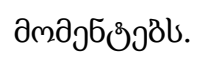

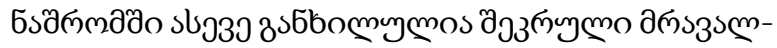

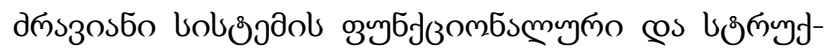

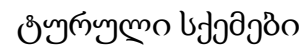

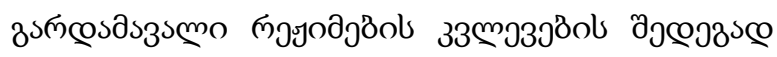

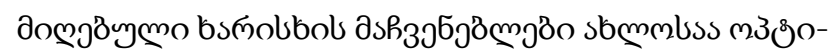

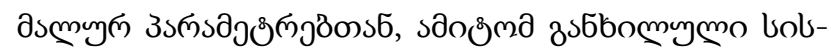

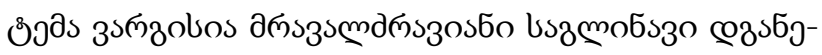
òobozol.

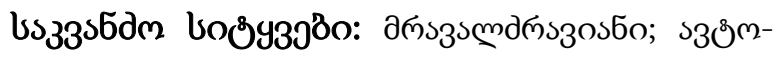

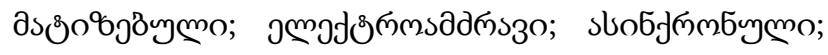

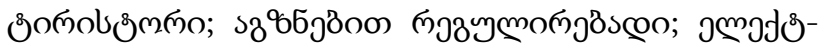
๓млдапзио м๓ 


\section{gjuszsmo}

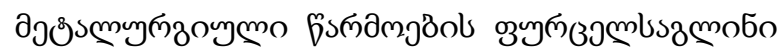

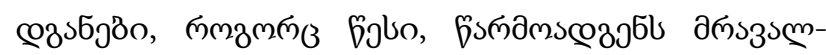

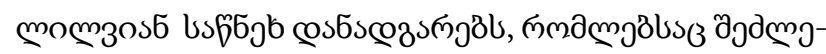

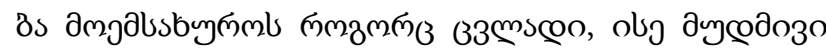

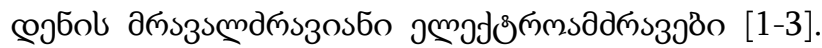

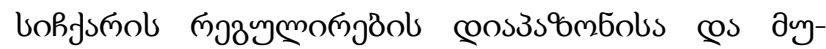

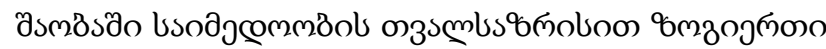

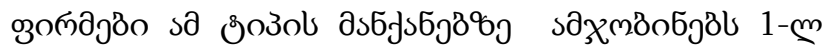

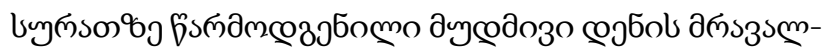

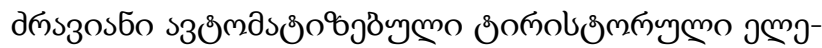

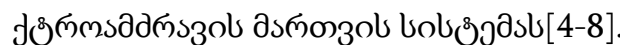

\section{donoosceo бsf̧оmo}

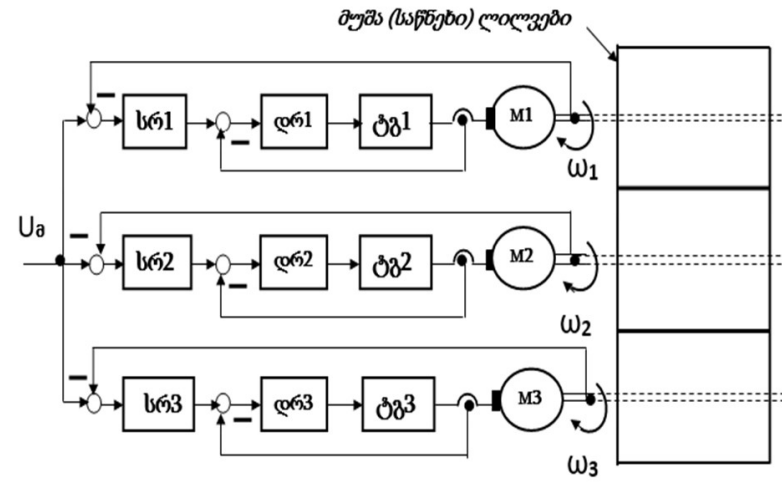

เขต๓. 1

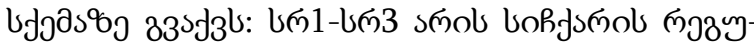

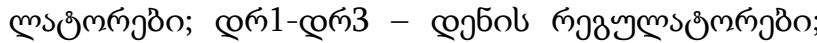

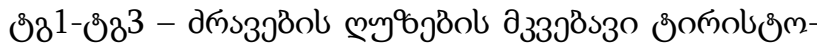

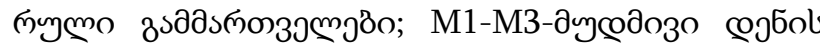

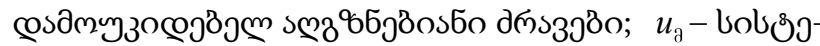

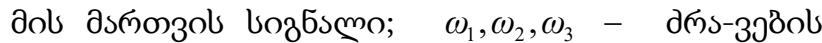

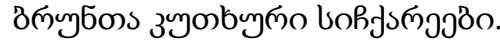

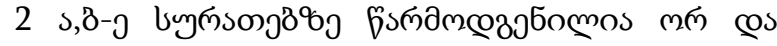

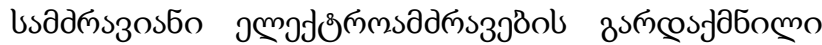

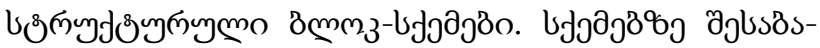

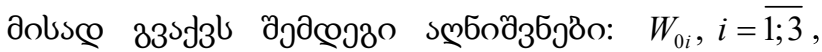

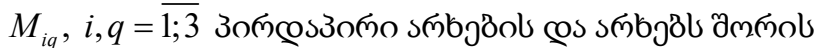

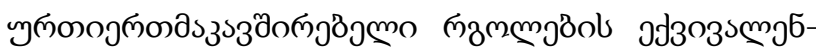

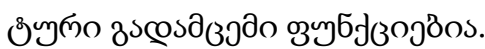

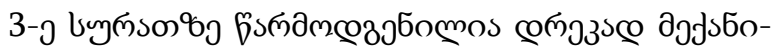

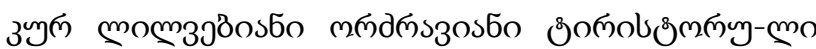

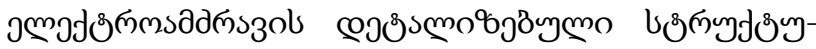

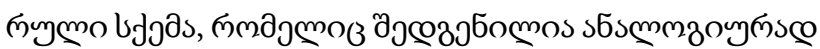

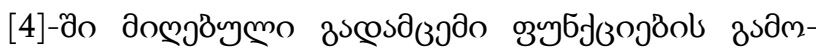
у

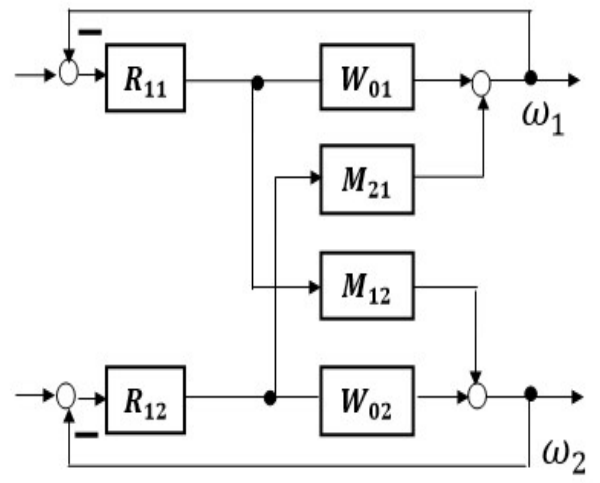

s)

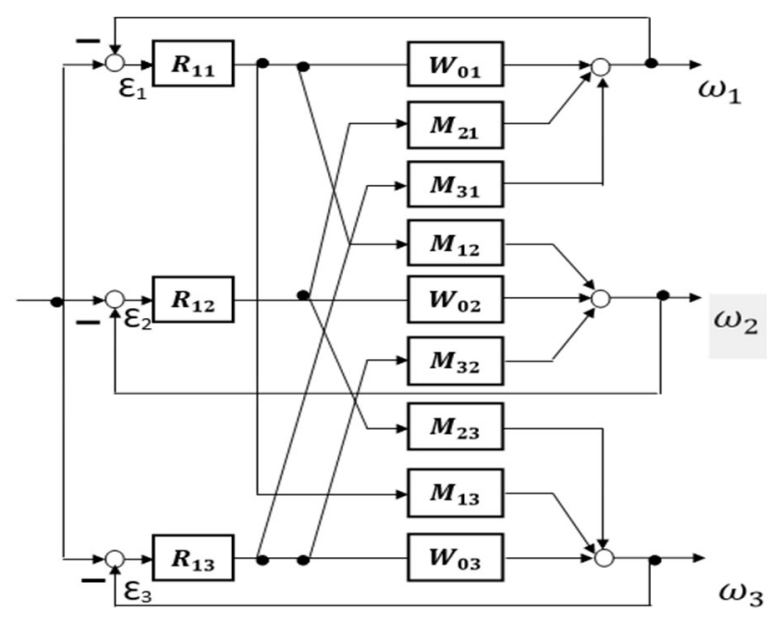

3)

เงตัต. 2 


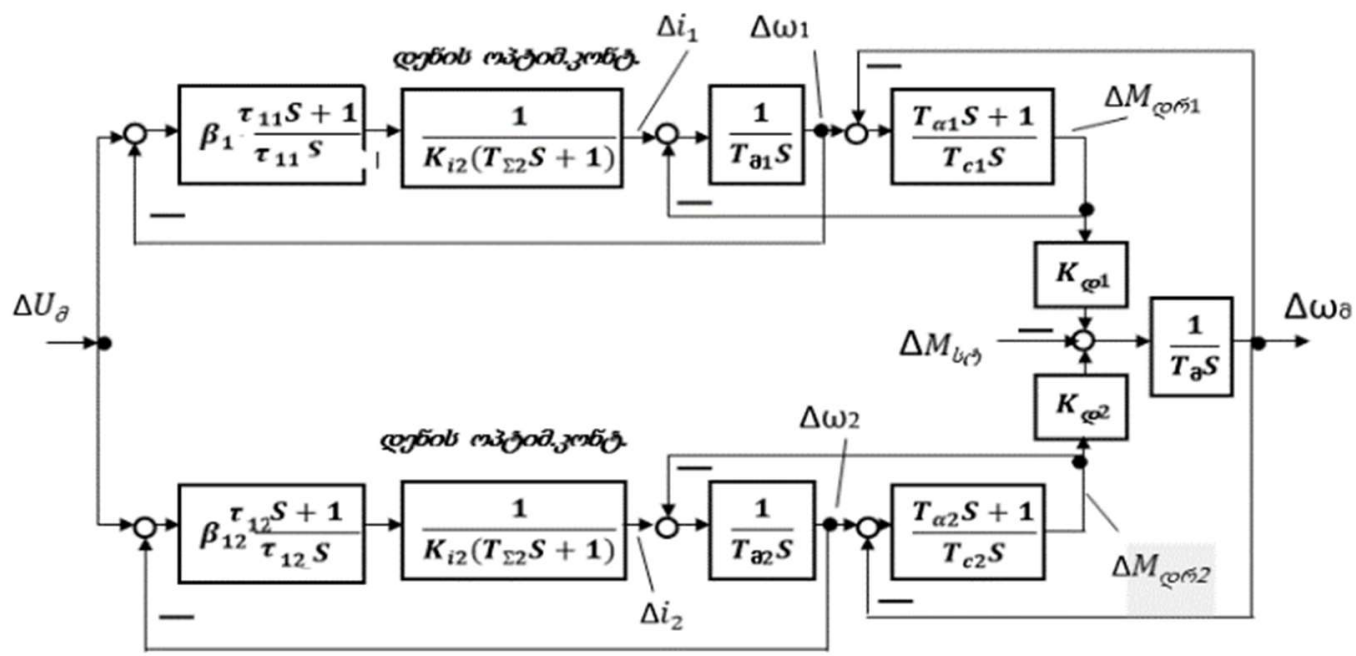

เumต. 3

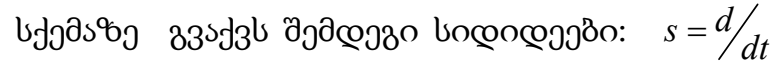

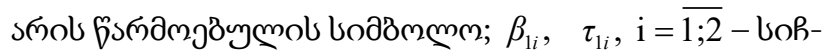

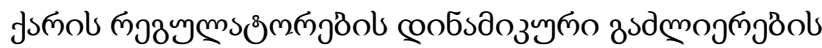

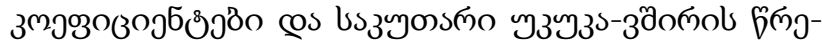

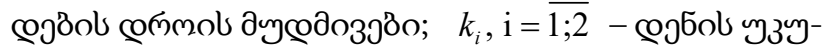

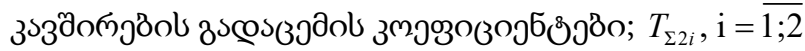

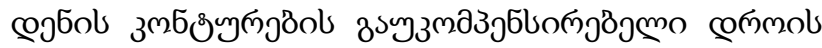

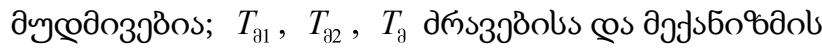

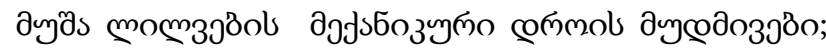

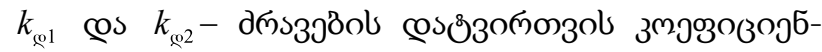

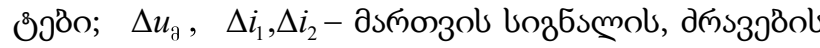

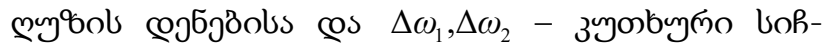

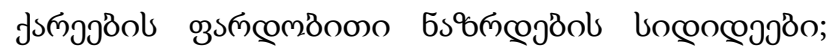

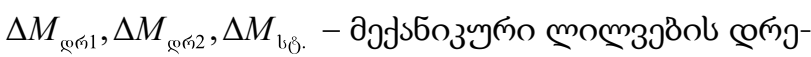

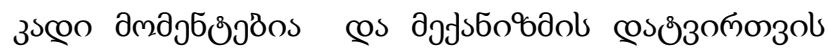

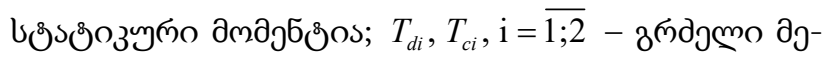

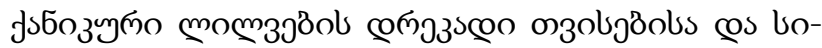

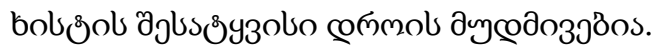

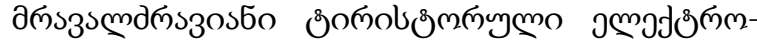

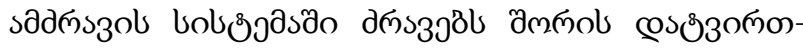

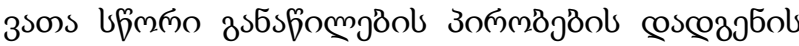

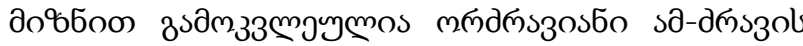

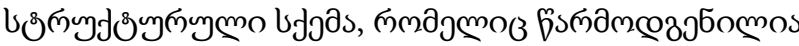

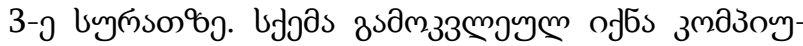

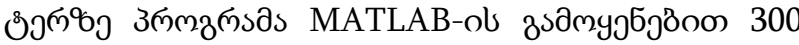

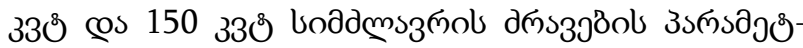

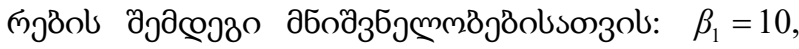
$\tau_{1}=0,1$ ба., $\quad \beta_{2}=8, \quad \tau_{2}=0,3$ gа., $\quad k_{i 1}=k_{i 2}=0,1$, $T_{\Sigma 2}=0,01$ ба., $T_{a 1}=1,5$ ба, $T_{\partial 2}=1,2$ ба., $T_{\text {ə }}=10$ ба. $k_{\mathrm{g} 1}=0,6, \quad k_{\mathrm{g} 2}=0,4, \quad T_{d 1}=T_{d 2}=0,002$ 6а.

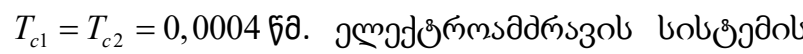

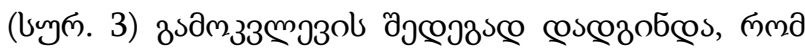

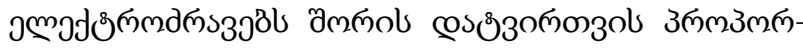

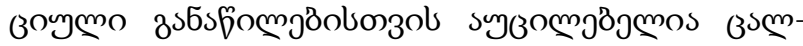

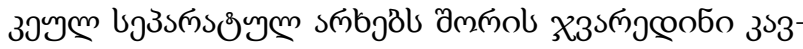

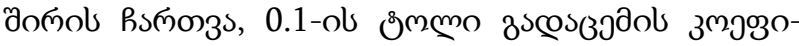

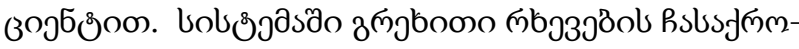




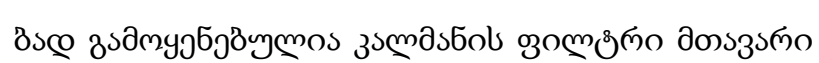

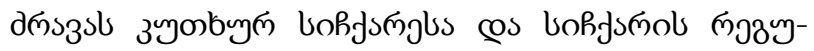

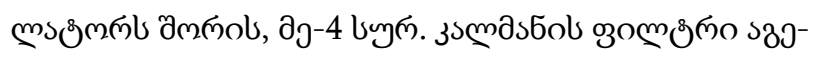

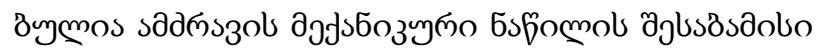

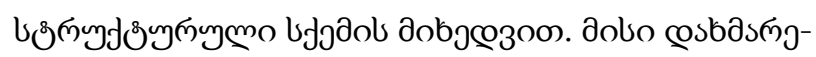

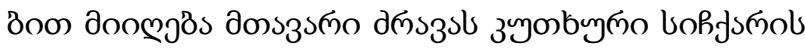

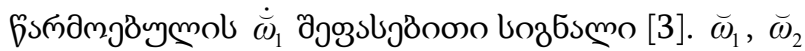

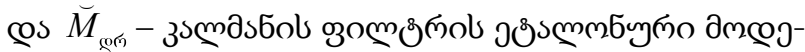

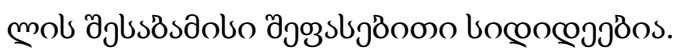

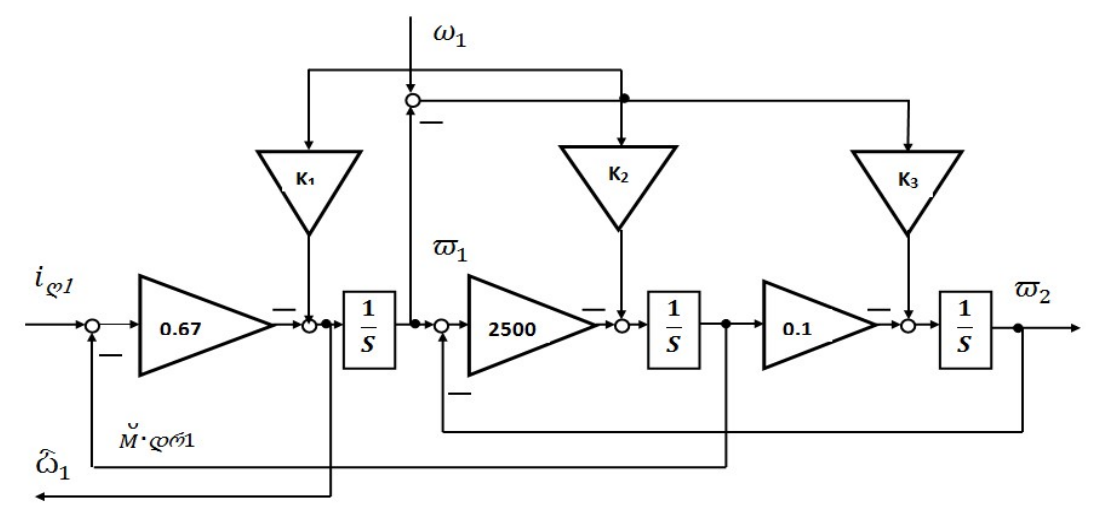

bynn. 4

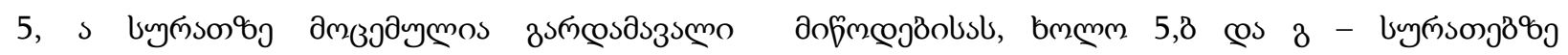

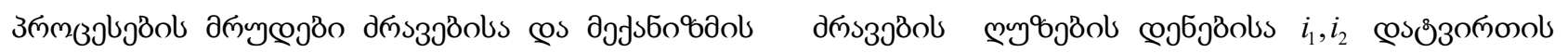

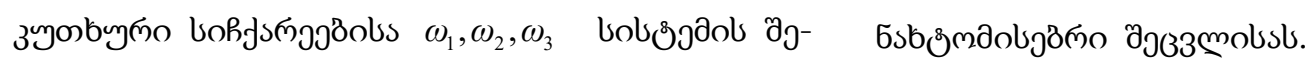

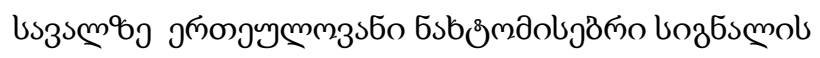

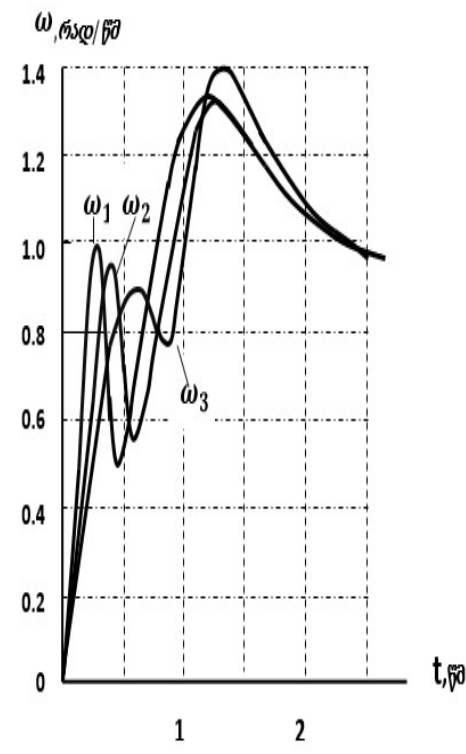

s)

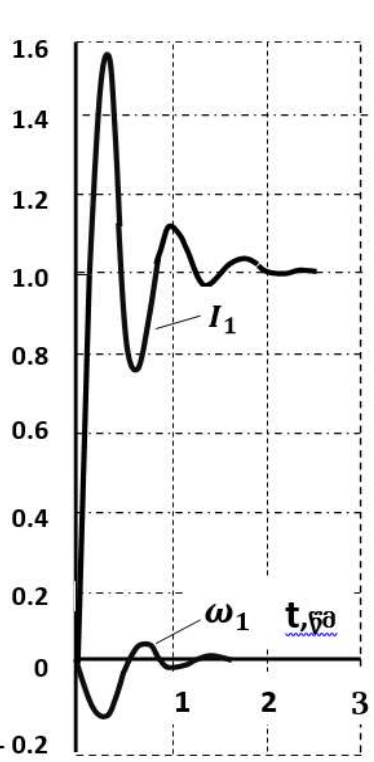

8)

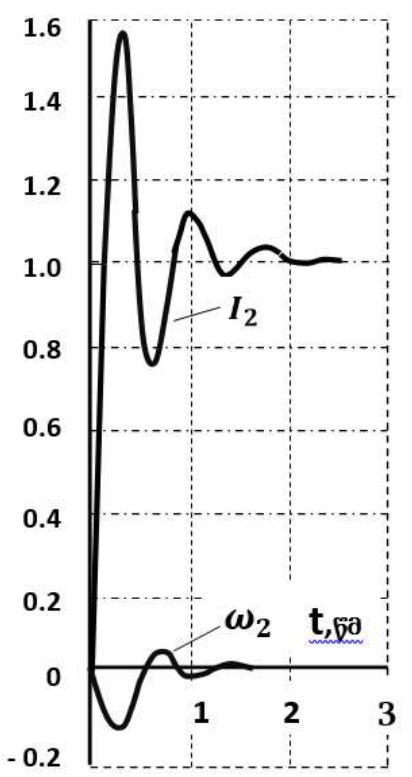

8)

เyตn. 5 


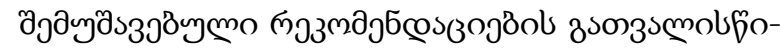

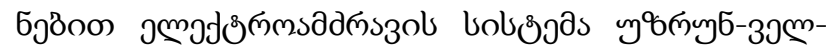
ymogl consanzyn asbstosongämgal bsলnoubol aga-

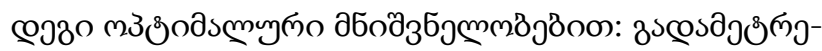

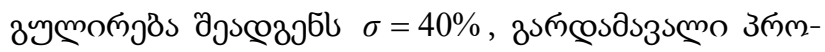

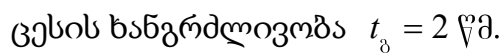

\section{cosb $336 s$}

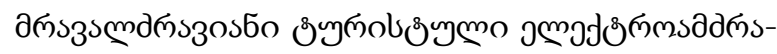

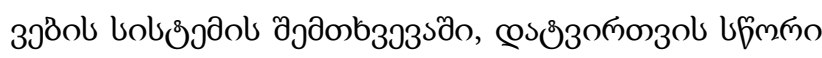

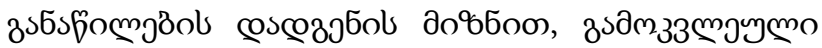

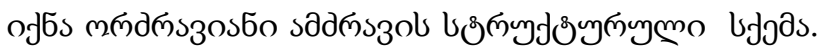

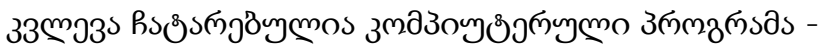
MATALAB - ob zsamyjбjöon 150330 es 3003308

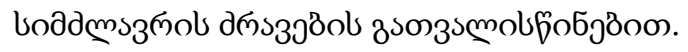

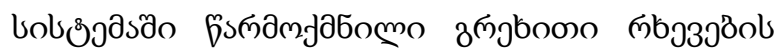

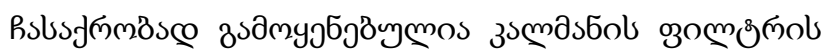

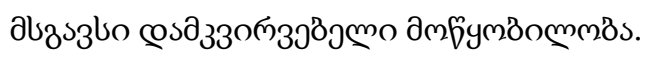

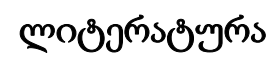

1. Dochviri, J., Khachapuridze, O., Beradze, N. (2015). A Digital Filter for Electrical Drive with Elastic Shaft. American Journal of Electrical and Electronic Engineering , 3 (5), 112-116. (In English);

2. Dochviri, J., Khachapuridze, O., Beradze, N. (2016). Dynamics of Digital System of Two-Motor Electrical Drive with Elastic Transmissions. American Journal of Electrical and Electronic Engineering , 4 (1), 16-22. (In English);

3. Dochviri, J. (2020). Configuration of the control system of an asynchronous electric drive with an observing device in the presence of an elastic mechanical shaft, Russia: Electromechanics, 1, 38-42. (In Russian);

4. Dochviri, J., Khachapuridze, O. (2012). Modeling the dynamic modes of a two-motor electric drive taking into account the elasticity and clearances of mechanical transmissions. Ukraine: Electrical and Computer Systems, 05 (81), 43-49. (In Russian);

5. Dochviri, J., Beradze, N. (2016). Dynamics of a two-motor electric drive with regulation of excitations of motors with digital control. Ukraine: Electrical and Computer Systems. Proceedings of the II International Conference. ELTECS-2016, 22 (98), 28-32. (In Russian);

6. Dochviri, J. (2005). Optimization of the dynamics of a thyristor electric drive with an elastic link according to the Kalman-Frobenius criteria. Electricity, 1, 26-31.

7. Dochviri, J. (2006). Optimization of transient processes of multi-motor thyristor electric drives with elastic connections for press mechanisms of continuous technological machines. Electricity, 2, 34-42.

8. Dochviri, J. (2002). Multi-motor automated electric drive with elastic connections. Ukraine: Radio Electronics, Informatics, Management, 1(7), 114-119. (In Russian). 
UDC 621.313.13

SCOPUS CODE 2102

https://doi.org/10.36073/1512-0996-2021-3-69-75

\title{
Dynamic Characteristics of a Multimotor Electric Motor Multichannel Control System, Taking Into Account the Elasticities of Mechanical Transmitters
}

\author{
Nana Beradze Department of Energy and Electronics, Georgian Technical University, Georgia, \\ 0160, Tbilisi, M. Kostava75 \\ E-mail: beradzenana@gmail.com \\ Oleg Khachapuridze Department of Energy and Electronics, Georgian Technical University, Georgia, 0160, \\ Tbilisi, M. Kostava 75 \\ E-mail: o.khachapuridze@gtu.ge
}

\section{Reviewers:}

S. Mebonia, Leading Specialist of the Institute of Mechanical Engineering of the National Academy of Sciences of Georgia

E-mail: meboniaseava@mail.ru

E. Korkia, Associate Professor, Faculty of Energy and Communications, GTU

E-mail: e.korkia@gtu.ge

Abstract. The study of the dynamic characteristics of two- and three-engine thyristor electric motors with constant current, in the case of a multi-motor control system, taking into account the elasticity of mechanical shafts are reviewed in this article. Such multimotor control systems are widely used in metallurgical production. For example, in sheet rolling mills, where in the mechanical part there are moments of significant dynamic curvature.

The paper also reviews the functional and structural schemes of a cohesive multi-engine system.

In the case of a multi-motor touring electric motor system, the structural scheme of a two-engine drive was studied in order to determine the correct load distribution. The study was conducted using a computer program MATALAB using $150 \mathrm{~kW}$ and $300 \mathrm{~kW}$ engines.

A Kalman filter-like observation device is used to quench the binding oscillations generated in the system.

The quality indicators obtained from the transient mode studies are close to the optimal parameters, so the considered system is suitable for multi-motor rolling mills.

Key words: automated; asynchronous; electric motor; excitably regulated; electric drive with flexible connections; multi-engine; thyristor. 
UDC 621.313.13

SCOPUS CODE 2102

https://doi.org/10.36073/1512-0996-2021-3-69-75

\title{
Динамические характеристики системы многоканального управления многомоторного электродвигателя с учетом упругости механических передатчиков
}

Нана Берадзе

Олег Хачапуридзе
Департамент энергетики и электроники, Грузинский технический университет, Грузия, 0160, Тбилиси, М. Костава 75

E-mail: beradzenana@gmail.com

Департамент энергетики и электроники, Грузинский технический университет, Грузия, 0160, Тбилиси, М. Костава 75

E-mail: o.khachapuridze@gtu.ge

\section{Рецензенты:}

С. Мебония, ведущий специалист Института машиностроения Национальной академии наук Грузии E-mail: meboniaseava@mail.ru

Э. Коркия, ассоциированный профессор факультета энергетики и связи ГТУ

E-mail: e.korkia@gtu.ge

Аннотация. Рассматривается исследование динамических характеристик двух и трехмоторных тиристорных электродвигателей, в случае системы многодвигательного управления с учетом упругости механических валов. Такие системы многодвигательного управления широко используются в металлургическом производстве. Например, в листопрокатных станах, где в механической части присутствуют моменты значительного динамического кручения.

В работе также обсуждаются функциональные и структурные схемы связанной многодвигательной системы.

В случае системы тиристорного электродвигателя, с целью определения правильного распределения нагрузки, была исследована конструктивная схема двухмоторного вала. Исследование проводилось с помощью компьютерной программы - MATALAB, с учетом двигателей мощностью в 150 и 300 кВт.

Для подавления беспорядочных колебаний, возникающих в системе, используется устройство мониторинга по типу фильтра Калмана.

Показатели качества, полученные при исследовании переходных режимов, близки к оптимальным параметрам, поэтому, рассматриваемая система подходит для многодвигательных прокатных станов.

Ключевые слова: автоматизированный; асинхронный; многодвигательный; регулируемое возбуждение; тиристор; электродвигатель; электропривод с гибкими соединениями.

\author{
зs6bom3ol os опомо 11.06.2021

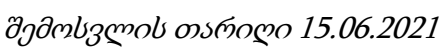

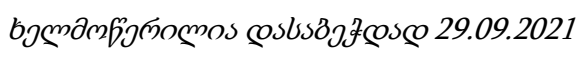

ISSN 1512-0996

www.shromebi.gtu.ge 